\title{
Surrogacy in Reproductive Medicine: Ethical and Legal Analysis of the Procedure
}

\author{
José Antonio García Pereañez ${ }^{1}$, Astrid Elena Lince Echavarría ${ }^{2}$ \\ ${ }^{1}$ Medicine Faculty, Universidad de Antioquia, American University Corporation, Medellin, Colombia \\ ${ }^{2}$ Medicine Faculty, Universidad de Antioquia, Legal Office of the American University Corporation, Medellin, \\ Colombia \\ Email: jgarciap@coruniamericana.edu.co, astridlince@coruniamericana.edu.co
}

Received 18 February 2016; accepted 24 May 2016; published 27 May 2016

\section{Abstract}

This text sets out the different arguments regarding surrogacy as a reproductive medicine technique in Colombia. The procedure is described, as well as the legal matters that this issue generates. Gestational carriers appear as an alternative for couples who want to have a child but they are not able to conceive because of infertility issues and do not want to go through an adoption process. Therefore, they adhere to surrogacy as an alternative of assisted human reproduction; a procedure that in Colombia faces serious legal gaps and causes ethical dilemmas in the collective imagery. These situations suggest an open discussion through a dialectics between the scientific progress advances, the lack of legal regulation and the constants against ethical positions that the surrogacy procedure causes in Colombia and other parts of the world.

\section{Keywords}

Reproductive Medicine, Gestational Carrier, Ethics, Legal, Colombia

\section{Introduction}

The surrogacy practice in Colombia had an "indifferent" position on the part of the Constitutional Court in the past. Additionally, because of the non-existence of a legal procedure that prohibited it, an approval was tacit. This was a very expensive intervention, usually requested by wealthy people who could afford to cover the costs of previous genetic studies, the in vitro fertilization, the implant of a fertilized egg in a gestational carrier, besides the costs of the pregnancy monitoring, delivery and post-partum.

Recently, on March 8, 2016, in a case without precedents, a political party of Centro Democrático promoted the initiative of proposing to the Colombian Republic Congress the prohibition of surrogacy through a bill. This proposal is justified on the arguments presented by the members of the congress, Maria Del Rosario Guerra and Santiago Valencia who vehemently state that surrogacy is an onerous practice of women's exploitation. They consider that surrogacy has been understood in Colombia as the act of contracting a woman who promises to gestate a baby with the compromise of giving him to the requestors when he is born. These requestors promise to raise the baby, so the surrogate mother must renounce the filiation. 
This initiative is based on a technical, legal, social and ethical study on this issue, and it intends to prohibit surrogacy in Colombia. In the last commemoration of the International Women's Day, the members of the congress Guerra and Valencia explained to the Colombian media that the surrogacy practice contained all the elements of a clear exploitation of women, as human beings and as mothers, ignoring de facto the protection of the newborn resulting from this practice of assisted fertilization.

The aforementioned bill was presented on March 9, 2016 to the secretary office of the Chamber of Representatives for the Colombian Republic Congress [1] to start the discussion of the proposal. In this project, the following topics are highlighted: the definition of the concept of surrogacy, the prohibition of this practice in order to protect the right to dignity, privacy, equality, autonomy, procreation and to women's health, as well as the future baby's right to live and constitute a family.

Some geneticists in Colombia support the surrogacy practice; they even name it as "the version of modern motherhood". This was a subject of analysis by the Colombian Constitutional Court in the first days of September, 2014 [2] when they highlighted the adoption by homoparental couples as long as the minor was a biological child of one of the parents. For this reason, surrogacy and artificial insemination were proposed to have the possibility to be a parent. Back then, the magistrate Luis Ernesto Vargas, president of the Colombian Constitutional Court, encouraged the republic congress to legislate on the surrogacy subject as an assisted fertilization practice, assuming that the only jurisprudence that existed in this regard was present in the Sentencia T 968 of 2009 [3].

According to Dr. Emilssen González de Cansino, Director of the Study Center on Genetics and Law from Universidad Externado de Colombia [4], the lack of regulation over surrogacy practices has generated serious legal problems for the children resulting from a surrogacy practice, especially in filiation-related issues, which becomes a gap over a legal right: offspring. The Colombian Constitutional Court, in its only pronouncement on the issue, stated that the legal gap had generated "harmful and irreparable decisions and facts of the fundamental human rights of the children involved". Additionally, it stated that substitute motherhood was a positive mechanism to solve the infertility problems of couples, and had evinced "the urgent need to regulate this subject to avoid, for example, the profitable mediation among the parts who make an agreement with this, the lack of legal protection of the child's rights and the considerable conflicts that emerge when there are disagreements among the parts" [4].

In Colombia, there is a legal agreement about the donation of eggs and the artificial insemination according to Decreto 1546 of 1998 [5], but that is not the case with the surrogacy practice. That is why many genetic centers in the country refuse to carry out this procedure; the legal gap is evident and there is not any law to guarantee that the baby will be given to the one who pays for this practice.

In the surrogacy practice, serious questions arise regarding the kinship among the baby who was born as a result of this practice, the substitute mother and the couple who will legally be the legitimate parents. Therefore, to establish the relationships between the conceived baby and the substitute mother, it is advisable to make a difference between gestational substitute motherhood and genetic substitute motherhood. In the first case, the hired mother receives an embryo with which she does not have any genetic link. In the second case, the embryo belongs to the substitute mother, so the contract should include an attached informed consent with the compromise to give the newborn baby to the contracting mother. In some cases, an adoption process is carried out to avoid inconveniences in the future, just in the case that the hired mother does not want to give the baby after the birth.

In relation to adoption, the "Código de la Infancia y la Adolescencia" [6] in Colombia states: "Adoption is mainly a protection measure through which, under the supreme surveillance of the state, the paternal-filial bond among people who do not have it by nature is irrevocably established.

There must be other means different from adoption to settle the relationship between the conceived baby and the substitute mother in order to avoid any attempt of consanguinity claim. According to the Colombian legal system, the substitute mother is considered as the real mother, since she herself gave birth to a baby who was the result of a surrogacy practice. This is not so, however, if a contestation process is invoked in accordance with court sentence, as the Artículo 335 of the Colombian civil code establishes [7].

The right to have a child is focused from the adult's point of view-people who claim to have the right to reproduce, which leads to the consideration of the child as an object and not as a subject. The "objectification" of the human being, that is, to treat humans as objects, is one of the prices paid for the sake of artificial procreation. If the legal constructs such as parental authority and adoption, that appeared in Roman law [8] to benefit the pater-familiae or those who did not have offspring to receive their inheritance, went through a transformation into institutions whose concern was the children's welfare, whether biological or adopted, there was no reasoning for 
artificial insemination not to preeminently watch the rights of the child resulting from an artificial insemination.

Filiation is a legal institution that regulates the family relations of the child with his father or mother, and kinship is what links him with the whole family group, paternal and maternal. Ignoring the genetic origins may cause serious psychological damage to a healthy person. That is why it is paramount that this child is born and grows up in a stable family setting.

Colombia's position with respect to surrogacy has been analyzed or constructed from the unique pronouncement of the Constitutional Court and the legislative attempt that was presented. In this sense, surrogacy contracts are acceptable; they are, however, subjected to the fulfillment of certain compromises regarding the newborn baby and the avoidance of the gestational carrier's exploitation.

The critiques of the most moderated positions in relation to surrogacy focus on questions such as the following: what if the substitute mother or the contracting parents change their minds and regret about their decision? What would happen in the case of a multiple birth? What if the baby is born with a serious disability or disease? Is a payment or an economic reward acceptable? What are the children's rights under these conditions? These questions are relevant and deserve attention. That is why we believe that the Colombian state must legislate and control surrogacy practices in order to avoid abuses and prevent the potential difficulties that may arise in the process. It is also important to provide the involved parts with assistance, even after the baby's birth.

The surrogacy contract is legitimate, as long as it helps human beings to fulfill their expectations since it makes possible the opportunity to conceive and raise a child of their own, genetically; even though this baby has been gestated by another woman. However, if we view this possibility from a commercial and economic perspective, the philanthropy and altruism that this practice had is set aside, and consequently, it adjusts to a reality in which the commercial sense predominates over the human sense. It is exactly in this setting where the discrepancies between the advances of scientific techniques and the human fragility emerge.

Taking into consideration the concerns previously mentioned and being aware that the surrogacy contracts are legitimate, in the case that a judge had to deal with a litigious matter of this nature, he would need to motivate his decision with the support of the proportionality test since in these sorts of situations there are not generalities; each specific case has distinctive features that oblige the judge to ponder the constitutional principles immersed in the concrete case, starting from the postulate that none of them has a higher hierarchy than the other. Therefore, considering the collision this public servant faces, he should decide for the selected principle that represents a higher benefit than the detriment of the not selected.

It cannot be denied that the surrogacy practice is a reality. Therefore, law as a regulation tool of social actions must assume a clear position towards this practice. In this respect, the Mexican approach to the surrogacy practices can inspire the Colombian legal structure which lacks a jurisprudence and legislative treatment towards this subject; without forgetting, of course, that our moral, social and political conditions will be the ones that determine its management.

\section{The Procedure}

Reproductive medicine has had an important development in the last years, especially in relation to assisted human reproduction techniques. According to María Inés Awad Cucalón and Mónica Narváez Cano [9], artificial insemination is defined as an artificial deposit of sperm cells into the woman's reproductive tract; depending on the origin of the semen's insemination, it can be: 1) Homologous: when the husband or male couple's gametes are used in the insemination process. 2) Heterologous: when the gametes of a third couple are used. 3) Mixed: when the homologous and heterologous procedures are combined.

The in vitro fertilization (IVF) process can be described as the union of the male and female gametes; a procedure that takes place in a laboratory through a test tube. The fertilized egg is implanted in the woman's uterus to continue with the pregnancy process. Artificial insemination can be 1) Homologous: when the eggs or the sperm cells are taken from the couple. The variable is when the woman is infertile because of a lack of a functional uterus but she has ovaries, so in the fertilization process, her eggs and her husband's sperms cells are used, but this embryo must be transferred to the uterus of another woman with the previous agreement that after the baby is born, he will be given to his genetic parents, modality known as gestational carriers. 2) Heterologous: when the eggs and the sperm cells obtained belong to a third partner who has previously donated them. In the case that none of the gametes come from the spouses or permanent couples, we would be facing an embryo donation because once it is obtained it is transferred to the uterus of the recurrent mother. 3) Mixed: it takes place 
when the insemination is done with the husband or permanent couple's sperm cells of the woman who is going through this procedure.

\section{The Colombian Case}

Surrogacy is one of the assisted human reproduction techniques; its procedure responds to a homologous in vitro fertilization that has arisen critiques and controversy in Colombia, especially because of the commercial diffusion of the procedure. A lot of women offer themselves as gestational carriers through social networks and other media. This contrasts with the legal dispositions on civil matter, on the validity and nullity of the contract, besides the legal criteria to determine the legitimate filiation of the child resulting from the surrogacy.

Additionally, the filiation and the contractual alliance do not have a clear procedure in the Colombian regulation, even with the existence of the legal criteria that is expressed through Ley 721 [10], Ley 1060 [11] and Ley 108 [12] that theoretically define and characterize the contractual situation and filiation matter. However, it is precisely in filiation and contract matters where surrogacy as a reproductive medicine technique finds serious difficulties.

It is a reality that the surrogacy practice has not been an uncommon procedure in Colombia; its diffusion oddly appeared because some inconveniences with the contract and the filiation were exteriorized. As a result, it was not possible to settle the conflict because of the non-existence of a legal construct that support the fundamental purpose of surrogacy: the procreation by a couple with infertility or sterility difficulties who request the surrogacy of a third woman who offers her womb in "leasing" or "loan", and in which the fertilization and the delivery takes place.

In pursuing a legal exit to settle the conflict that arises with the surrogacy practice offered through the in vitro fertilization technique, and with the firm intention to legally and legitimately clarify the filiation, it is mandatory to invoke a legal procedure that is part of the existing regulation in Colombia: adoption. The in vitro fertilization technique has high costs; a fact that facilitates the procreation and conception through this reproductive medicine technique only to wealthy people. This brings a risk that the likely adoption process does not grant the legal filiation of the child resulting from this technique to the hiring couple.

It is therefore important to highlight that in the last decade in Colombia, several bills have been presented to the Republic Congress with the intention of getting a weighted legislation on assisted human reproduction techniques, and specifically on surrogacy. Unfortunately, they have not prospered and have been removed, an evidence of the little acknowledgement that the Colombian legislation offers to scientific advances, especially when they cause confrontations between the ethical and legal aspects, as it is evident in surrogacy practices.

Sooner or later, the Colombian legislation will understand that the scientific and technological advances are present to improve the human being's lives, and that the legal and ethical criteria that is discussed in the surrogacy practices will be useful, not to question the axiology of the collective imagery, but to harmonize the society values and the current legislation with a new anthropological dimension that supports and guarantees the self-determination of individuals as a foundation and principle of their dignity, in accordance with the free development of personality, the management of the own body and self-care that include the constant scientific reality in the legal procedures

\section{Discussion}

In order to determine the foundations of the discussion about surrogate mothers as a reproductive medicine technique, it is necessary to precise the following: individuals are able to make autonomous decisions that affect their lives [13]. All individuals can manage their body and the development of principles such as autonomy, the conception of their own human dignity, the free development of their personality and the creation of their own family. That is why it is so important that the Colombian legislation mediates fundamental agreements between the new scientific reality and the law.

The legal discourse about surrogate mothers has been nuanced with ideological opinion criteria and moral, legal, economic and biological factors; all of them are differently understood, which becomes an obstacle in the legislative advances related to this issue. This determines the configuration of an ethical dilemma of pragmatic type that involves the moral and legal concept of family. It also involves the progress in the development of individual freedoms that the neo-constitutionalism, dominant in Colombia, has been able to gradually conquer through new legal reasoning that emerges as a guarantee of personal autonomy. 
The subject of surrogacy in Colombia is critical and controversial, not only because of its legal implications but also because of its double moral argumentation that moves between laxity and contestation. In addition to this, there is a proliferation of classified advertisements in interactive webpages that offer services, prices and benefits of gestational carriers who appear to be young, vigorous, willing to submit to a surrogate motherhood with the guarantee that they will not resort to any legal procedure to retain the baby; on the contrary, with a good remuneration, they will give him free or charge.

Surrogate motherhood is the response that reproductive medicine offers to solve infertility problems, a situation that affects a considerable amount of the population. According to the Revista Colombiana de Obstetricia y Ginecología [14], infertility is a condition that $16 \%$ - $20 \%$ of couples in reproductive age face. According to the Latin-American net of assisted reproduction [15], the causes are originated as follows: $40 \%$ in women, $40 \%$ in men and $10 \%$ in the couple; the remaining $10 \%$ is originated in diverse causes such as accidents, diseases, among others. Many people who suffer infertility use the assisted reproduction techniques such as artificial insemination and in vitro fertilization.

\section{Conclusions}

Colombia lacks regulation regarding surrogacy. It is necessary to take into consideration the pronouncements of the constitutional court, especially in relation to the children's rights to know their real filiation as a guarantee to access justice and the effective enjoyment of their rights.

Through the interpretation of the constitutional parameters related to the rights to freedom, the free development of personality, and the right to have a family, we can project the feasibility of an application to assisted human reproduction. However, the limits are in the person's dignity, especially when it is assumed that the human existence starts from the fertilization moment. The Colombian civil law does not consider the embryo as a person to protect his life, though; a parameter that has been weighed enough by the Tribunal Constitucional which demands respect for the gestational state of a woman, and of course, the new life she has inside.

In relation to the legal and ethical dilemma of surrogacy, there are two positions; the first is the majority's, which takes into consideration the evaluation criteria that have impregnated the law and makes it difficult to go against the legal and constitutional tradition. As a result, it is understood that the embryo is a human being that enjoys especial protection and should not be manipulated. The second is a more liberal position that advocates for the individual freedom, the free development of personality, the freedom to constitute an own family and the rights to precreation, and indicates that the cultural and legal models should change the way that individuals relate with the scientific advances, especially in assisted human reproduction techniques.

\section{References}

[1] Colombia. Secretaría de la Cámara de Representantes. Proyecto de Ley, para prohibir la maternidad subrogada en Colombia. Moral. [Internet]. Bogotá. http://congresovisible.org/proyectos-de-ley/por-medio-del-cual-se/8306/\#tab=2

[2] Colombia. Corte Constitucional. Admisión auto del magistrado Jorge Iván Palacio. Ampliación adopción parejas del mismo sexo, en tanto sean hijos biológicos de alguna de las personas involucradas. Bogotá. http://congresovisible.org/admisiónautomagistradojorgeivánpalacio

[3] Colombia. Corte Constitucional.Sentencia T 968 [Internet]. Corte Constitucional, Bogotá. http://www.corteconstitucional.gov.co/relatoria/2009/T968.htm

[4] González Cancino, E. (2004). Secretaría de Senado República de Colombia. Recuperado el 03 de Marzo de 2010, de Audiencia Pública Proyecto de 77 ley 029 de 2003. http://www.secretariasenado.gov.co/estudios-ARD/018\%20T\%E9cnicas\%20de\%20Procreaci\%F3n\%20Humana\%20A sistida.pdf

[5] Colombia. Ministerio de Salud y Protección Social (1998) Decreto 1546 [Internet]. El ministerio, Bogotá. http://www.medicinalegal.gov.co/documents/10180/16629/Decreto+1546-1998.pdf/04f0f531-0525-4942-b5d9-2f85b5 $\underline{\mathrm{b} 2412 \mathrm{e}}$

[6] Colombia. Congreso de la Republica (2006) Ley 1098 Por la cual se expide el Código de la Infancia y la Adolescencia. Diario Oficial, Bogotá., No. 46.4446. http://www.ins.gov.co:81/normatividad/Leyes/LEY\%201098\%20DE\%202006.pdf

[7] Colombia. Código Civil (1983) Bogotá, 1983. Art. 335. http://www.secretariasenado.gov.co/senado/basedoc/codigo procedimiento civil pr011.html\#335 
[8] Arguello, L. (1990) Manual de Derecho Romano, Historia e Instituciones de Derecho Romano. $3^{\text {a }}$. Edit, ASTREA, Buenos Aires.

http://www.buenastareas.com/materias/resumen-de-manual-de-derecho-romano-de-arguello-luis-rodolfo/0

[9] Awad Cucalón, M.I. and Narváez Cano, M. (2001) Aspectos jurídicos en las técnicas de la reproducción asistida humana en Colombia. Tesis para optar al título de Abogado. Pontificia Universidad Javeriana. Facultad de Ciencias Jurídicas, Bogotá.

[10] Colombia. Congreso de la República (2001) Ley 721. http://www.icbf.gov.co/cargues/avance/docs/ley_0721_2001.htm

[11] Colombia. Congreso de la República (2006) Ley 1060. http://www.alcaldiabogota.gov.co/sisjur/normas/Norma1.jsp?i=20855

[12] Colombia. Congreso de la Repùblica (2006) Ley 1008. http://www.alcaldiabogota.gov.co/sisjur/normas/Norma1.jsp?i=18869

[13] Colombia. Constitución Política. Artículo 16: Todas las personas tienen derecho al libre desarrollo de su personalidad sin más limitaciones que las que imponen los derechos de los demás y el orden jurídico. http://www.constitucioncolombia.com/titulo-2/capitulo-1/articulo-16

[14] Brugo Olmedo, S., Chillik, C. and Kopelman, S. (2006) Definición y causas de infertilidad. Revista Colombiana de Obstetricia y Ginecología, 54, 19-23.

[15] Red Latinoamericana de Reproducción Asistida. http://redlara.com/

\section{Submit or recommend next manuscript to SCIRP and we will provide best service for you:}

Accepting pre-submission inquiries through Email, Facebook, LinkedIn, Twitter, etc.

A wide selection of journals (inclusive of 9 subjects, more than 200 journals)

Providing 24-hour high-quality service

User-friendly online submission system

Fair and swift peer-review system

Efficient typesetting and proofreading procedure

Display of the result of downloads and visits, as well as the number of cited articles

Maximum dissemination of your research work

Submit your manuscript at: http://papersubmission.scirp.org/ 